\title{
Issues Relating to Collateral Requirements Imposed upon Alien Reinsurers of United States Ceding Insurers
}

\author{
Ernst Csiszar \\ Property Casualty Insurers Association of America (PCI), Des Plaines, IL, U.S.A. \\ E-mail: ernst.csiszar@pciaa.net
}

Due to the growth in the international nature of the reinsurance market, there has been increasing pressure in the United States (U.S.) for a system that would permit alien reinsurers, those assuming business from U.S. domiciled ceding companies, a reduced level of collateral, provided certain conditions were met. Support for this change has come from Lloyds, the London market and other non-U.S.-based reinsurers, and a small number of U.S.-based ceding companies. There has been strong opposition to this from U.S. reinsurers, most U.S. primary companies and others. This paper will give an overview of the U.S. reinsurance collateral requirement and discuss issues with perspectives from both sides. It is not the intent of this paper to advocate any position on the issue.

The Geneva Papers (2005) 30, 522-532. doi:10.1057/palgrave.gpp.2510043

Keywords: reinsurance; reinsurance collateral; solvency; insurance regulation; enforceability of judgements; accounting standards; mutual recognition

\section{Introduction}

The business of reinsurance plays a significant economic role. What we typically think of as insurance assists businesses in shifting certain areas of risk inherent in conducting their business. Capital shies away from activities that carry a significant danger of catastrophic loss. It tends to move toward less risky activities. Similarly, insurers themselves need to transfer an amount of their risk. One way this is done is through reinsurance. In a nutshell, reinsurance is insurance for insurers. Reinsurance can cover differing elements of the insurer's risk, such as natural catastrophes, large losses on single policies (facultative reinsurance), large losses on similar kinds of policies (treaty reinsurance), or a portion of all the losses with similar risk factors (quota share reinsurance). These are but some of the forms of reinsurance.

There are a number of benefits to those insurers that reinsure their business. Reinsurers can provide unique expertise related to specific kinds of risk. Financially, reinsurance can improve the position of the ceding company; this can happen in a number of ways. Generally, insurers that transfer or "cede" risk to assuming reinsurers may take a "credit" on their financial statements for reinsurance. One effect of this credit is that, to the extent of the credit, a portion of the capital of the insurer is "freed up" for additional business as the balance sheet of the insurer is improved by the credit. This increases the capacity of that insurer to write more business. This is called "surplus relief" provided by reinsurance. From a regulatory standpoint, however, that credit for the reinsurance is only as good as the likelihood of the reinsurer paying its obligations when due. 
In the United States (U.S.), the reinsurance business can be divided into two parts. The first part is reinsurance business that is assumed by reinsurers licensed in at least one state in the U.S. Those reinsurers are fully regulated in the same manner as any other U.S.-based insurer. The remainder of the business is assumed by reinsurers that are not licensed in any state, "alien reinsurers". States attempt to regulate reinsurance transactions indirectly, not by imposing restrictions directly on the assuming reinsurer, but rather by imposing conditions under which the ceding company can take credit for reinsurance on its financial statement ("annual statement").

The National Association of Insurance Commissioners (NAIC) adopted a model law and regulation relating to under what circumstances a ceding company may take credit for reinsurance. The NAIC's Credit for Reinsurance Model Act and Credit for Reinsurance Model Regulation provide a number of ways in which a ceding insurer may take credit for reinsurance. The first pertains to those situations where the reinsurer is licensed to do business in the ceding company's domiciliary state. The reinsurer is fully subject to the financial requirements and reporting of that state, including minimum capital and surplus, and is subject to the NAIC's risk-based capital formula. These reinsurers must also file a financial statement based on the NAIC's statutory accounting principles (SAP), including a CPA audit and an actuarial opinion. It also includes being subject to the full gamut of insurance regulation in that state.

The next two ways in which ceding companies can take credit for reinsurance are: the reinsurer is an accredited reinsurer in the ceding company's domicile, or the reinsurer is domiciled in a state that has credit for reinsurance standards similar to that of the domicile of the ceding company. Effectively, the reinsurer is, in the former case, filing for approval, or, in the latter case, has been licensed in a state. The state licensing the reinsurer, while not the ceding company's domiciliary state, must have substantially similar standards to that of the ceding company's domiciliary state. In either case, the reinsurer, effectively, will be subject to NAIC statutory accounting standards and state regulation. The fourth situation is where the reinsurer has established a multiple beneficiary trust where funds equal the aggregate U.S. liabilities as to all its reinsurance agreements plus a surplus of at least \$20 million (or for Lloyds, $\$ 100$ million). ${ }^{1}$

Finally, we come to the situation upon which this paper focuses: where credit for reinsurance is granted to the ceding company where the reinsurer has posted security equal to the sum of its U.S. liabilities under the relevant reinsurance agreement. This security may be in a number of forms: letter(s) of credit, trust funds, or funds withheld. There are applicable regulations specifying the format for these forms of security. ${ }^{2}$ There is no requirement of any surplus in addition to collateral as in the case of a multiple beneficiary trust.

It is this requirement of posting collateral that a number of alien reinsurers of U.S. ceding companies have proposed for some time now. They have suggested that there be a system under which the collateral be reduced from 100 per cent of liabilities to 50

\footnotetext{
${ }^{1}$ NAIC Model Regulation Section 7(A) and 7(B)(1)

${ }^{2}$ NAIC Model Regulation Section 9(A).
} 
per cent (and 30 per cent for affiliates). One proposal is that there be a list of reinsurers, approved by the NAIC or some affiliate thereof, or a commissioner. The process would be similar to that currently used for alien surplus lines insurers under which the alien surplus lines insurer files financial and other data with the NAIC. These data are reviewed and a determination of eligibility to write surplus lines is made. To date, the NAIC has not taken action on such a list for reinsurers, but is examining the issues cited in this paper to see if such a list could be established.

It is noteworthy that recently nine U.S. regulators released a letter to the U.S. property and casualty and reinsurance trade associations stating alternatives to the 100 per cent collateralization rule that should be considered. Those regulators called for alternatives that would facilitate:

- enhanced reporting from reinsurers to regulators, consistent with U.S. reporting requirements;

- a better matching of a ceding insurer's credit and the assuming reinsurer's reserves;

- a reduction in coverage disputes between cedents and reinsurers; and

- a pass-through of the savings achieved in reinsurance costs to the cedent and ultimately to the primary policyholder. ${ }^{3}$

No action has been taken by any group at the NAIC as to the adoption or rejection of the independent positions of the nine regulators as of its spring meeting in March 2005. With this as background, we now move to particular issues concerning collateral reduction and the positions of the parties.

\section{Market issues}

Proponents of collateral reduction cite collateral as an unnecessary additional cost to the insurance transaction where the reinsurer has a proven track record of financial soundness. One such cost happens when the alien reinsurer, in posting collateral, effectively, is unable to use those assets for any other business purpose. This reduces the capacity for the reinsurer to reinsure other businesses. There are transaction costs in the determination of the amount of collateral to be posted, actual transfer of assets, and issuance of a letter of credit, if so chosen as the collateral. While the reinsurer may retain the investment income from the collateral, it may not be the best economic use of those assets. The rates of return on deposits held by ceding companies are often far lower than would actually be earned by reinsurers on these funds, and the practice of requiring deposits actually increases the cost of insurance (leading to higher premiums). ${ }^{4}$

Collateral is cited by the proponents as being unnecessary from established, strong solvent alien reinsurers. They claim it is really a trade issue, with the U.S. being unduly protectionist. Proponents of collateral reduction also do not accept that reduction of

\footnotetext{
${ }^{3}$ November 17, 2004 letter to the trades from regulators in the following jurisdictions: Arkansas, California, District of Columbia, Georgia, Illinois, Maine, New York, North Dakota, Texas.

${ }^{4}$ KPMG (2002): Study into the methodologies for prudential supervision of reinsurance with a view to the possible establishment of an EU framework.
} 
collateral requirements will result in a race by reinsurers to operate outside the U.S. Rather, client demands, or more appropriately market demands, will determine where the reinsurers will be located. Reinsurers will likely, as they already do, have operations in and outside of the U.S. so as to serve client needs best.

Opponents of collateral reduction claim that there has not been evidence as to the extent collateral reduction will lower the cost of reinsurance in the event collateral is reduced. In fact, the U.S. reinsurance market itself has shown that imposing collateral requirements does not impede the entry of alien reinsurers in the U.S. market. NAIC research indicated that the alien reinsurers that do not establish a U.S. domicile now have approximately 45 per cent of the U.S. market, a significant amount. In addition, many large alien reinsurers have established an affiliate licensed in at least one state. When one includes those companies, the result is that 77 per cent of the U.S. reinsurance market, in one way or another, is ultimately controlled by non-U.S. entities. It is also of interest that these non-U.S. entities have established U.S. affiliates that reflect an additional 32 per cent of the market. Clearly, licensing in the U.S. is not a barrier to entry. Opponents claim that the collateral issue is not a trade issue as alien reinsurers can easily do business in the U.S. if they so choose. Rather, it is a solvency issue. Opponents of collateral reduction stress the need to consider credit risk and ultimately solvency in any determination of whether or not to reduce collateral.

\section{Solvency}

The primary concern of the U.S. reinsurers and the majority of domestic ceding companies with regard to collateral reduction relates to solvency. They feel that, should a major alien reinsurer become insolvent, the impact on the ceding company and the primary industry in the U.S. would be devastating. It is argued that collateral, even when posted at 100 per cent of outstanding liabilities, will, in reality, always be posted at a much lower number than the ultimate losses. The issue is alleged to be recognition of adverse development. For example, Morgan Stanley estimated that, in 2003 , property casualty insurers added $\$ 15$ billion to reserves. Here are some specifics from that year: AIG: $\$ 700$ million reserve increase ceded to non-affiliated reinsurers; ${ }^{5}$ Travelers: indications that $\$ 1$ billion was ceded to all reinsurers; ${ }^{6}$ ACE: $\$ 1.8$ billion ceded to reinsurers, ${ }^{7}$ Hartford: indications that $\$ 1.34$ billion was ceded to reinsurers. ${ }^{8}$ As ceding companies increase their losses by adverse development, this would require additional collateral from certain alien reinsurers to again attain the required 100 per cent of outstanding liabilities. Considering adverse development by ceding companies means that the proposal, with 50 per cent requirement for non-affiliates and 30 per cent for affiliates, will be even more severely underfunded with regard to collateral actually needed to cover the true losses of ceding companies.

\footnotetext{
${ }^{5}$ February 4, 2003, Best Wire, AIG Chair Maurice R. Greenberg, \$3.5 billion gross reserve increase.

${ }^{6}$ January 21, 2003, IBNR, Dowling and Partners newsletter.

${ }^{7}$ February 3, 2003, IBNR, Dowling and Partners newsletter.

${ }^{8}$ May 12, 2003, Press release, the Hartford, Hartford Announces Asbestos Results and Capital Plan.
} 
526

Opponents of collateral reduction believe that the insolvency of a major alien reinsurer is not an unrealistic scenario, given a recent period where the financial reports of alien reinsurers caused concern, such as those relating to Gerling. Should a reinsurer become insolvent, the effect would be widespread throughout the industry. Not only will the ceding companies be affected, but also the bulk of the primary insurers in the U.S. The ceding companies of that reinsurer would be hit directly, as they would be forced to absorb losses they thought had been handed off to the reinsurer. Opponents of collateral reduction raise points here regarding the approved list proposal. Should a reinsurer begin to have financial difficulty and collateral requirements are increased, for example, by removal of that alien reinsurer from the approved list, this will come at the very time when that reinsurer is in less of a position to post the collateral. In reality, establishment of full collateral, when most needed, will be impossible, and unlike approved alien surplus lines insurers the effect will be felt, not by a limited number of insureds directly insured by the defunct surplus lines carrier (insureds that make an affirmative choice to place business with a particular surplus lines company through a licensed surplus lines broker), but rather by insureds that in all likelihood had no choice as to the reinsurer, most likely no knowledge of, or choice as to, the particular reinsurer being involved with their insurance. Finally, should a ceding company's reinsurer become insolvent or that ceding company's reinsurance become uncollectable, it may mean the insolvency of that ceding company. That would be catastrophic in and of itself, but an alien reinsurer's insolvency could also mean, perhaps, the insolvencies of many companies ceding to that reinsurer. In those cases, state guaranty funds will have to pay the claims of the insolvent ceding company or companies, placing the cost of uncollectable reinsurance on the majority of the insurers in the U.S.

If and when reinsurance recoverables are paid are two important issues that also raise concerns as to the timing of when to implement any change in collateral requirements and the financial ratings of insurers. Recently, disputes between insurers and reinsurers have been on the rise. Two of the more famous disputes relate to the Lloyd's central fund and the World Trade Center's "Two Occurrences or One" dispute, but disputes have become more widespread to include such areas as asbestos losses. Disputed claims rose more than $\$ 1$ billion in 2003, with disputed recoverables "over 90 days" almost five times larger than those "over 90 days" not in dispute. ${ }^{9}$ Related to the increase in the number and the timing of disputes is the growth in recoverables relative to surplus. In 1999 and 2000, the ratio of reinsurance recoverables to insurer surplus was less than 1:1. This grew to 1.37:1 and 1.39:1 in 2001 and 2002, with some improvement in 2003. When the adequacy of reinsurers' loss reserves is considered, the recoverables to reserves plus surplus ratio in 2003 shows a 6 per cent deterioration since $1995 .{ }^{10}$ Ultimately, this affects insurer ratings. A.M. Best has told Commissioner Mike Pickens, then NAIC President, that its Best Capital Adequacy Ratio (BCAR) imposes charges on companies for the credit risk on reinsurance recoverables, impacting the risk profile of ceding companies. According to

\footnotetext{
${ }^{9}$ Conning and Company, "Reinsurance Recoverables: Mind the Gap", 2004.

${ }^{10}$ Conning, ibid.
} 
A.M. Best, less collateral could result in a lower A.M. Best rating. ${ }^{11}$ Other rating agencies may similarly consider the collateral in their determinations of company ratings.

Opponents of collateral reduction have within their ranks some regulators and the liquidators of insolvent insurers in the U.S. who have expressed concerns that collateral reduction will impact existing companies and insolvencies. In 2002, Commissioner Diane Koken, now president of the NAIC, stated before a committee of the National Conference of Insurance Legislators (NCOIL): “ ... accepting less than 100 per cent collateral from reinsurers that are not subject to U.S. regulation would have an even greater impact on financially sound ceding insurers as they become forced to incur increased costs in attempts to collect funds in foreign judgments". ${ }^{12}$ It is important to note here that the same International Insurance Issues Committee before which Ms. Koken made that statement voted to adopt the "Approved List of Reinsurers Model Act", the proposal sought by a number of alien reinsurers. The Insolvency Task Force of the NAIC, made up of regulators focusing on issues relating to guaranty funds and liquidations of insurers, on January 29, 2003 voted not to support the proposal to reduce collateral, citing difficulties in the collection of reinsurance recoverables of a company in liquidation. The task force heard, among others, testimony from the Ohio liquidator of three reinsurers of insolvent companies. The first was a U.S.-based reinsurer that fully commuted 100 per cent of the present liabilities to commute the treaty. The second was a non-U.S. reinsurer with trust funds fully covering liabilities that paid 100 per cent of present liabilities to commute the treaty. The third was a non-U.S. reinsurer, without collateral posted, that refused to commute and was very slow in paying. ${ }^{13}$ The lack of collateral was alleged to result in poorer cooperation by that reinsurer.

In countering the claim that collateral is necessary from alien reinsurers to protect the solvency of ceding companies, proponents point out that recently there has been a number of large commercial insolvencies of fully regulated U.S. primary companies such as Reliance, Fremont, and Legion. These companies went insolvent with direct reserves totaling over $\$ 9.2$ billion. ${ }^{14}$ Or from another perspective, in the fully regulated U.S. market, state insolvency guaranty funds have had to pay out, in relation to companies that were fully regulated in the U.S., \$5.6 billion in 2001-2003, compared with $\$ 10.4$ billion from 1969 to 2000 . As mentioned earlier, these guaranty funds assess the bulk of the primary insurers in the U.S. for the cost of these insolvencies. This is not the sign of a marketplace that does a good job of ensuring the solvency of the primary companies it fully regulates, yet alone that of reinsurers. Proponents of collateral reduction maintain that fully regulated uncollateralized reinsurers can pose as much if not more of a solvency threat to ceding companies as collateralized alien insurers, yet no collateral is required of those entities. Rather, the approved list, under

11 June 18, 2003 letter from Mr. Matthew Mosher, Group Vice President, A.M. Best to Mike Pickens, President, NAIC.

${ }^{12}$ M. Diane Koken, Pennsylvania Insurance Commissioner, Testimony before the National Conference of Insurance Legislators (NCOIL), International Insurance Issues Committee, 2002.

13 NAIC Proceedings: Conference Call of the Insolvency Task Force, January 29, 2003.

${ }^{14}$ NAIC Annual Statement Data. 
which any reinsurer, including U.S. domestic reinsurers, could participate, would be based on a single standard for all reinsurers: operational and financial strength. Therefore, weaker reinsurers, wherever situated, would be required to post collateral. Stronger reinsurers would still post collateral, but on a reduced basis. Collateral would be posted where needed, not determined by geographical location of a reinsurer.

\section{Enforceability of judgements}

The collectibility of reinsurance recoverables relates directly to the ability of an insurer to enforce judgements in other jurisdictions. This applies to ongoing insurance entities and the regulators and liquidators who attempt to collect reinsurance recoverables as they manage the estates of insolvent companies. If judgements are potentially uncollectable, there is an added credit risk to ceding companies that purchase reinsurance from reinsurers in jurisdictions where failure to honour judgements makes the reinsurance uncollectable. As might be expected, both sides in the collateral debate disagree as to exactly how enforceable U.S. judgements are in foreign jurisdictions. We will start with the proponents of collateral reduction.

The proponents contend that there has not been a single case raised demonstrating a real problem of enforceability of judgements. Rather, they claim that the countries where the vast majority of alien reinsures are domiciled enforce U.S. judgements. This has been borne out by senior members of the NAIC task force and specific, detailed documents from countries such as the U.K. (including enforcement of default judgements), France, and Germany. As a general rule, judgements of U.S. courts are enforced by these jurisdictions. It is further clear from the level of trade between Europe and the U.S. amounting to over $\$ 1$ billion per day that judgements relating to commercial disputes are enforced. Finally, arbitration awards are enforced pursuant to existing treaties.

On the other side, it claimed that while, for example, the U.K. does afford a degree of certainty to U.S. judgements in commercial relationships, the review of U.K. law did not address, for example, punitive or multiple damages, the latter which will not be enforced in the U.K. It is possible in the U.K. that a U.S. default judgement not be honoured. In France, it is possible that a U.S. judgement in favour of a U.S. insurer to collect from the officers of a French company would not be honoured. Germany does not enforce awards of punitive or exemplary damages, or excessive damages. In Switzerland, judgements will be enforced against parties to the agreements, but not necessarily a non-party, such as, in the event of the insolvency of the ceding company, a regulator or receiver (this may be the case in many other jurisdictions as well). Anecdotal evidence of enforcement difficulties exists pertaining to: Brazil, Finland, France, Greece, Italy, Japan, Korea, Philippines, Turkey, Uruguay, Venezuela and currency fluctuation issues pertaining to enforcement of U.S. judgements in Bulgaria and Romania. Nor is the U.S. a party (currently) to any treaty regarding the enforceability of judgements, leaving enforceability up to the laws of that country. The U.S. State Department has gone on record as stating that: "Our best information is that law and practice in most foreign countries are not generally favourable to the prompt, predictable enforcement of U.S. civil judgments...In a substantial number 
of other countries, the written law appears to be more favourable than actual practice." 15

In an attempt to address the issue of enforceability of judgements, the NAIC has joined the efforts of the International Association of Insurance Supervisors (IAIS) and the International Bar Association to clarify that insurance and reinsurance contracts are not excluded from the Hague Convention, even if related to one of the named exemptions. It is believed that such an action will increase the certainty that judgements will be enforceable.

\section{Mutual recognition}

This topic encompasses a wide variety of factors relating to ascertaining the solvency position of a reinsurer, including: technical provisions such as risk management on the liability side; capital and surplus requirements; investment and liquidity including asset risk management; reporting requirements; holding company systems; and corporate governance policies. In the narrow sense, mutual recognition addresses whether or not two countries have comparable accounting systems. In the broader sense, this addresses just how similar or different each country's overall regulatory system is.

On the accounting side, proponents claim that there is precedent for reconciliation of differing accounting systems. The NAIC's International Insurance Department (IID) analyses the financial statements of alien insurers wishing to accept surplus lines business from non-U.S. surplus lines companies in the U.S. The IID may receive financial statements from surplus lines insurers located in countries that vary widely as to the underlying accounting principles, yet is able to review those statements and make judgements as to whether or not the entity should be approved for surplus lines business in the U.S. Proponents of collateral reduction claim that their proposed approved reinsurer listing would operate in a similar manner. They maintain that the regulators do have the ability to evaluate differing financial statements of alien insurers and determine their financial soundness. They also cite reinsurance risk to a ceding company as being no different from the credit risk that lies in corporate bonds. These are accepted as admitted assets of insurers, yet it is conceivable that these bonds may be a much greater credit risk than a highly rated, alien reinsurer that has been in existence for decades. Also, the proponents point out that, presuming a total failure of those alien reinsurers without any collateral whatsoever, U.S. reinsurers' overall exposure would be only approximately 3 per cent of the aggregate balance sheet of the U.S. property casualty industry.

The other side contends that the wide divergence in financial reporting (U.S. GAAP, the more conservative U.S. SAP, U.K. GAAP, and the accounting practices in other countries) will make it difficult for any entity to evaluate the financial status of any given reinsurer. Opponents claim that the differences in standards result in wide differences, citing that, in one particular year, ING Group reported a \$4.6 billion ${ }^{15}$ Letter from Jeffrey D. Kovar, Assistant Legal Advisor for Private International Law, U.S. Department
of State to Mike Pickens (then) President, NAIC: Recognition and Enforcement of Foreign Judgments. 
profit under Dutch financial standards and a $\$ 10.4$ billion loss under U.S. GAAP. AXA reported a $\$ 1$ billion profit under French accounting standards vs. a $\$ 3.1$ billion loss under U.S. standards. Opponents claim also that it is inappropriate to compare approval of non-U.S. reinsurance business to approval of non-U.S. surplus lines business. In the latter, there is no guaranty fund safety net in the event of an insolvency, and the parties affected by the insolvency of a non-U.S. surplus lines carrier chose that carrier with the help of a licensed insurance professional, the surplus lines broker. The non-U.S. reinsurer's insolvency, it is claimed, would affect thousands of insureds of primary companies that, due to the insolvency of its reinsurer, in turn may itself become insolvent. The ceding company's insolvency would add pressure on other primary companies to cover claims through guaranty fund assessments. Furthermore, it might not just be the one ceding company that becomes insolvent, but potentially many ceding companies, thereby magnifying the problem. They claim that this would seriously stress the U.S. guaranty fund system, already pressured by a spate of recent insolvencies.

The other elements of mutual recognition relate directly to the level of regulation a jurisdiction imposes on its domiciled reinsurers. Proponents of collateral reduction argue that the concept of mutual recognition is not crucial for the U.S. to approve reinsurers for the purpose of collateral reduction. Precedent exists within the IID of the NAIC approving non-U.S. surplus lines insurers. However, it appears that for collateral reduction to become a reality in the U.S. the issue of mutual recognition will need to be addressed.

Rather than analyzing the specific regulatory approach in each jurisdiction, we describe some general points. Many non-U.S. countries do not impose the same level of supervision of reinsurers that the U.S. does. U.S. domiciled reinsurers are regulated on the same basis as primary companies. The trend internationally is towards greater regulation of reinsurers. In fact, for example, the U.K. regulates the company market in the same way as direct U.K. insurance business. This applies to licensing requirements, reporting requirements, and solvency requirements. ${ }^{16}$ For the Lloyd's market, emphasis is placed on risk, resulting in perhaps even tighter regulation. For example, syndicates are required to produce Realistic Disaster Scenarios, identifying the potential exposure to major losses. This is risk-based, rather than rule-based, with a risk-based capital formula and, where appropriate, a capital loading. Syndicates are rated from 1 (least good) to 4, with the lowest two ratings subject to capital loading. ${ }^{17}$

The NAIC is currently analyzing the elements of mutual recognition. Internationally, there is movement towards uniformity. The IAIS has adopted its Principles on Minimum Requirements for Supervision of Reinsurers (October 2002) and its Standard on Supervision of Reinsurers (October 2003). Combined, the Principles and Standards address the requirements for licensing, fit and proper testing, and on site inspection. They go on to consider technical provisions, investment and liquidity,

${ }^{16}$ KPMG, Study into the methodologies for prudential supervision of reinsurance with a view to the possible establishment of an EU framework, 2002.

${ }^{17}$ KPMG. 
capital adequacy, corporate governance, and exchange of information. At the NAIC, the workplan in this area is to inventory current IAIS work, including a survey of supervision in the various jurisdictions, identify principles needed for mutual recognition, and identify areas where further work is needed. The IAIS expects to adopt at its October 2005 meeting eight "cornerstones" to assess insurer solvency.

The European Union (EU) is also considering elements that can lead to mutual recognition. One such element is the Directive on Financial Conglomerates. There are within the directive capital adequacy requirements that include the reinsurance undertakings of entities in a group. There is a goal of a single coordinating supervisor for such groups. Perhaps more critical to the subject of this paper is the directive on reinsurance. There are no harmonized reinsurance supervision rules within the EU. The current differences in the level of supervision of reinsurers between different EU member states are significant. ${ }^{18}$ The proposed Directive on Reinsurance as put forward by the European Commission looks towards applying the same rules as those for direct writers upon reinsurers. The "Solvency II" project which looks into monitoring solvency will likely impact the directive with regard to reinsurers. Ideally, this would result in a reinsurer becoming licensed in a single EU member state and then being able to write in other member states without regulation by those other member states. However, these processes have a long way to go to establish the standards necessary for effective mutual recognition.

\section{Conclusions}

A basic problem inherent in the current discussion relating to reduction of collateral for non-U.S. reinsurers doing business in the U.S. is that, to some degree, arguments made by both sides are dealing with an "apples and oranges" scenario. For example, U.S. reinsurers claim that they are disadvantaged by the costs of full U.S. style regulation, while the proponents of reduction feel that they are disadvantaged by the costs of collateral. Similarly, proponents claim that it is a trade issue. Opponents say there are a number of ways in which alien reinsurers can reinsure U.S. cedents: licensing, accreditation, forming a trust, or posting sufficient collateral. Opponents say it is more of a solvency issue. Given that reinsurance is international in scope, the goal should be to achieve good, consistent regulation of reinsurers on a global basis. Only then is it appropriate to speak of geographic neutrality or, more bluntly, a level playing field. Progress is being made in these areas, but, given the complexity of issues, will take some time. Clearly, the work at The Hague in assuring that judgements relating to insurance and reinsurance are enforced in all jurisdictions is a step forward. However, that is in the early stage of proposed language. Adoption of the language remains to be seen. On the financial side, mutual recognition is slowly moving forward. The standards as outlined by the IAIS and the EU Directives are positive steps, but only steps toward mutual recognition. Much remains to be done.

\footnotetext{
${ }^{18}$ International Association of Insurance Supervisors, Global Market Report 2003, December 2004.
} 


\section{About the Author}

Ernst Csiszar is currently president and chief executive officer of the Property Casualty Insurers Association of America, a property casualty trade association in the United States with over 1,000 members writing over $\$ 154$ billion in premium. Prior to that, Mr. Csiszar held the position of president of the National Association of Insurance Commissioners and was the insurance director for the state of South Carolina. 